https://helda.helsinki.fi

\title{
The Northern Way : Graves and Funerary Practices in Corded Ware Finland
}

\author{
Ahola, Marja
}

2020-06

Ahola, M \& Heyd , V 2020 , ' The Northern Way : Graves and Funerary Practices in Corded pÿWare Finland ' , Praehistorische Zeitschrift , vol. 95 , no. 1 , pp. 78 111 . https://doi.org/10.1515/pz-2020-0002

http://hdl.handle.net/10138/330637

https://doi.org/10.1515/pz-2020-0002

Downloaded from Helda, University of Helsinki institutional repository.

This is an electronic reprint of the original article.

This reprint may differ from the original in pagination and typographic detail.

Please cite the original version. 


\title{
Author's Accepted Manuscript \\ Final published version of the article is available at
}

https://doi.org/10.1515/pz-2020-0002

Praehistorische Zeitschrift 95 (1) 78-111

\section{Marja Ahola, Volker Heyd \\ \#Head 1\#The Northern Way: Graves and Funerary Practices in Corded Ware Finland}

\begin{abstract}
The Corded Ware complex represents an archaeologically defined culture whose people inhabited large areas of Europe during the third millennium BC. Although Corded Ware graves are known also from Finnish territory - the northernmost area of Corded Ware expansion - these graves represent a special challenge and methodological problem for archaeological research. This is because unburnt bone material is generally not preserved in the acidic soils of Finland, and Finnish Corded Ware complex graves have typically been recognized mainly due to the occurrence of a Corded Ware assemblage (i.e. complete pottery vessels, adzes and ground-stone axes). Furthermore, since most Finnish Corded Ware grave discoveries have been made during the early and mid- $20^{\text {th }}$ century, they generally lack goodquality archaeological documentation. Despite these challenges, new insights into Finnish Corded Ware burials can be gained by thoroughly investigating the region's burial customs and material culture as an entity and comparing them to the Corded Ware complex of the eastern Baltic region and beyond. Finnish Corded Ware graves not only follow the standard material culture and burial customs of the Central European Corded Ware complex but show additional evidence of wooden chambers and laid-out furs, and they may have occasionally even possessed small mounds. However, even though the material culture of the Finnish graves follows traditions present in the central European Corded Ware complex, the grave custom is far from uniform. Hence, Finnish Corded Ware graves represent a melting pot of ideas, ideologies and connections, likely reflecting differing origins of relocating people. Aside from being influenced by the Corded Ware populations of nearby regions, a close link to contemporary local hunter-gatherers seems to have been present, too.
\end{abstract}

Keywords: Corded Ware complex; graves; funerary practices; eastern Baltic region; Finland

Marja Ahola: University of Helsinki, Department of Cultures, Archaeology, P.O. Box 4, FI-00014 University of Helsinki, Finland. E-Mail: marja.ahola@helsinki.fi; 
Volker Heyd: University of Helsinki, Department of Cultures, Archaeology, P.O. Box 59, FI-00014 University of Helsinki, Finland. E-Mail: volker.heyd@helsinki.fi

\section{\#Head 2\#Introduction}

Towards the end of the Neolithic, large areas of central and eastern Europe were populated by the Corded Ware/Single Grave/Battle Axe complex (henceforth CWC), that is, people using in the most basic sense - cord-decorated ceramic beaker vessels and shaft-hole axe-heads.

Since CWC settlement sites are only rarely encountered in central and northern Europe ${ }^{1}$, the complex has traditionally been known from grave finds that, compared to prior mortuary traditions, stand out due to novel funerary practices $^{2}$. Corresponding to the many wellpreserved graves documented from different regions in Europe, these new practices include individual internments in an overall E-W/W-E orientation, positioning the body into a basically crouched position (with gender differentiation based on the orientation of the body), and furnishing the grave, for example, with battle axes, cord-decorated beakers and amphoras, often in addition to stone adzes, sometimes bone tools, and bone and amber pendants and ornaments, likewise prescribed by gender and placed in relation to the body ${ }^{3}$.

In contrast with the well-preserved graves in neighbouring areas, the Finnish CWC graves represent a special challenge for archaeological research. This is because unburnt bone material is generally not preserved in the acidic soils of Finland, and Finnish CWC graves have typically been recognized mainly due to the occurrence of a Corded Ware assemblage (e.g. complete pottery vessels, adzes and ground-stone axes) ${ }^{4}$. Although most of these artefacts technically have to be declared as stray finds, on some rare occasions the artefacts have also been unearthed together with a grave-like pit structure of stained or sooty soil ${ }^{5}$ (Figure 1). Since fragments of human molar enamel were discovered from one of these structures together with two stone adzes, a grinding stone and sherds of Corded Ware pottery ${ }^{6}$, it seems reasonable to assume that such features are indeed CWC graves. In light of the scarce material, it seems that most of the Finnish CWC burials are earth graves, which are also common in the CWC distribution areas of northern and central Poland, the Baltic States and north-western Russia ${ }^{7}$. In Finland, the graves are usually referred to as solitary graves; occasionally organized in small groups ${ }^{8}$, sometimes they have also been

\footnotetext{
${ }^{1}$ Hecht 2007; Dörfler/Müller 2008.

${ }^{2}$ Furholt 2014, 70.

${ }^{3}$ Ibid. Fig 2; Bourgeois/Kroon 2017.

${ }^{4}$ See, e.g., Edgren 1970; Edgren 1984, 76-77; Nordqvist/Häkälä 2014.

5 Äyräpää 1931; Kivikoski 1936; Siiriäinen 1972; Torvinen 1979; Purhonen 1986.

6 Äyräpää 1931.

${ }^{7}$ Larsson 2009, 61 with cited references.

${ }^{8}$ Nordqvist/Häkälä 2014, 12.
} 
unearthed in prior hunter-gatherer cemeteries ${ }^{9}$. According to recent studies ${ }^{10}$, Finnish CWC graves may have more widely been furnished with animal skins, a tradition that has not been recorded from CWC contexts in any other part of Europe.

Given the above, it is clear that even if the Finnish CWC graves lack human skeletal remains, new insights into CWC mortuary practices can nevertheless be gained from these finds at the northernmost distribution area of the complex. It must be noted, though, that since the material mainly consists of archival sources or single papers published in Finnish, it is not easily accessible for the wider international research community. Accordingly, in this paper, the Finnish CWC graves will be presented in a single study. The aim of the paper is to get a critical overview of the archival material collected during the past hundred years and present it in relation to the current knowledge on $\mathrm{CWC}$, particularly with its counterparts in the Baltic states.

Before moving on to the discussion of funerary practices and the material culture from the graves, however, a brief outline of the Finnish CWC is appropriate here for those readers not so familiar with the area.

Cord-decorated pottery and battle axes associated with the CWC appear in the Finnish territory by ca. $2900 \mathrm{BC}^{11}$. At the time, the area of modern-day Finland was inhabited also by local hunter-gatherer populations producing asbestos- and organic tempered wares of the Late Comb-Ware tradition ${ }^{12}$ (e.g. so-called Pöljä Ware, Jysmä Ware and Pyheensilta Ware ${ }^{13}$ ). According to the distribution of the finds, the core area of Corded Ware habitation was in the southern and western areas of Finland, while finds from central and northern Finland probably being more intensively inhabited by some of these hunter-gatherer populations - are more scarce ${ }^{14}$. The appearance of the CWC in the Finnish territory has long been explained by migration ${ }^{15}$, and this is still a valid explanation, as we also stress later on.

Although migration theory has now found support by recent aDNA analyses, according to which a genetic transformation, probably relating to Yamnaya relocations from the Steppes, occurred in the $3^{\text {rd }}$ millennium $\mathrm{BC}$ in Europe ${ }^{16}$, how that migration unfolded in the various

\footnotetext{
${ }^{9}$ Torvinen 1979; Purhonen 1986; see also Ahola $2017 \mathrm{~b}$.

${ }^{10}$ Ahola et al. 2018.

11 Pesonen et al. 2019

${ }^{12}$ Nordqvist/Herva 2013; Nordqvist 2016, 53.

${ }^{13}$ Halinen 2015, 106-116.

${ }^{14}$ See, e.g., Äyräpää 1939; Edgren 1970; 1984; Nordqvist/Häkälä 2014.

15 Äyräpää 1973; Edgren 1984, 79; Matiskainen 1994; Carpelan 1999.

${ }^{16}$ Allentoft et al. 2015; Haak et al. 2015.
} 
regions remains totally unknown ${ }^{17}$. Indeed, many scholars have suggested that the CWC was not formed due to large-scale migrations but as the result of extensive networks, to which the local populations also contributed ${ }^{18}$. These two interpretations do not have to contradict each other, however. For example, in the Swedish territory the CWC was likely initiated via exogamy, in which skilled potters of the CWC tradition migrated to the Swedish territory and married local hunter-gatherers ${ }^{19}$.

Although the Finnish CWC accommodates larger numbers of settlement sites ${ }^{20}$, contrary to the rest of Europe, not much is known of the CWC way of life in the Finnish territory. Indeed, although the CWC has commonly been associated with mixed pastoral and cultivating economies $^{21}$, no preserved domestic animal bones dating to the Corded Ware period have been discovered in Finland so far $^{22}$. This, in conjunction with a lack of investigated macrofossil plant remains and the harsh environment of the north, has led some scholars to suggest that the Finnish CWC turned into a hunter-gatherer society ${ }^{23}$. However, since most CWC settlements have been discovered from locations suitable for farming as well as from phosphate-rich, old dwelling sites of earlier hunter-gatherers, it was nevertheless widely acknowledged that the CWC people of the Finnish territory also relied on pastoral farming ${ }^{24}$. This interpretation has recently been supported further by lipid analyses conducted on Finnish CWC pottery ${ }^{25}$, which have confirmed the presence of milk fats originating from domestic stock. In addition, goat hairs have also been discovered from the CWC grave of Perttulanmäki in southern Ostrobothnia ${ }^{26}$.

In light of these combined results, it seems plausible that domestic animals were present also at the northern periphery of the Corded Ware complex. Since the nature of the finds is indirect, the extent of the animal herding remains unknown. Perhaps in line with the findings of studies conducted outside the Finnish borders ${ }^{27}$, the Corded Ware populations of the Finnish territory likely practised a mixed economy, in which hunting, fishing and gathering still played a significant role. However, indisputable agricultural components remain to be found.

\footnotetext{
${ }^{17}$ Sjögren et al. 2016.

${ }^{18}$ Lõugas et al. 2007; Vander Linden 2007; Furholt 2014, Nordqvist/Häkälä 2014.

19 Larsson 2009

${ }^{20}$ Nordqvist/Häkälä 2014

${ }^{21}$ See, e.g., Hecht 2007; Lõugas et al. 2007; Larsson 2009, 71; Müller et al. 2009; Sjögren et al. 2016.

${ }^{22}$ Bläuer/Kantanen 2013.

${ }^{23}$ Furholt 2014.

24 Äyräpää 1939, 118; Edgren 1984, 75.

${ }^{25}$ Cramp et al. 2014.

${ }^{26}$ Ahola et al. 2018.

${ }^{27}$ Lõugas et al. 2007; Müller et al. 2009; Sjögren et al. 2016.
} 


\section{\#Head 2\#Materials and methods}

The research material of the study consists of all possible CWC graves currently (2019) known from Mainland Finland (Figure 2). The grave data was collected by the authors from publications, the Finnish Heritage Agency find catalogue (NM), and from unpublished excavation reports. By keeping in mind that the archaeological archives do not contain objective documents of past processes but are rather inflicted with the subjects involved ${ }^{28}$, the authors carefully read all the reports and collected detailed information (e.g. length, width and depth of pits, locations, find material) on each grave structure. In order to understand the excavation process, the written description was compared to the detail maps and photographs of the features when possible. For the purposes of this paper, the material is compiled in Appendix 1. A summary of the material is presented in Table 1.

During the archival study, the possible CWC graves were divided into three categories. The first category consists of what we think are secure graves (i.e. grave-like pit structures together with a typical Corded Ware grave assemblage). It must be noted, though, that even if we have labelled this category as 'secure graves', there are nevertheless several problems. The main problem is that in as many as eight cases, the finds were discovered as stray finds and the find context was mainly described orally by the finder. Since in most cases the artefacts were discovered by local laypersons and no immediate documentation was made, this information should be regarded with caution. Moreover, although 13 graves (of a total of 21 graves) have been excavated, in many cases the grave integrity had already been destroyed by modern land use before the excavations. Many of the excavations have also been conducted during the early and mid $-20^{\text {th }}$ century, and photographs or detail drawings/site plans of the graves are only rarely available.

The second category consists of stray finds (e.g. intact or halved pottery vessels or a groundstone axe or adze, together with sherds of Corded Ware pottery), discovered at a depth of ca. 0.5-1 metres, a depth that could indicate a destroyed CWC burial. The number of these sites is 11 . This category does not, however, include stray finds of battle axes - a common grave gift - without any other indication of a burial. This is due to the fact that battle axes could also indicate, for example, votive deposits ${ }^{29}$. Though this decision might create a bias in the material numbers, without preserved human remains it is impossible to make a distinction between a grave find and a votive deposit.

\footnotetext{
${ }^{28}$ Swain 2012.

${ }^{29}$ Johanson 2006.
} 
The third category in the Appendix is surely the most controversial. It consists of seven possible grave features without any find of material culture that have been unearthed from Corded Ware settlement sites. We have included this category because some of the Baltic CWC burials, for example, lack pottery and stone artefacts ${ }^{30}$. In the Finnish territory, such burials would easily go unnoticed since they would have been represented solely by an inhumation-sized and shaped archaeological feature. Although the features presented in the third category could comprise the remains of such inhumations, they could also be something else. Since reliable radiocarbon determinations are not available, the features could also succeed the Corded Ware period.

The lack of radiocarbon determinations affects the whole research material, leading to a deficiency of chronology; although radiocarbon dates are available in some rare cases, it must be noted that they have mainly been obtained from charcoal collected from the filling of the grave (Appendix 1). Because wood charcoal could also be found in the grave context due to a later forest fire or through the filling of the grave structure along with growing or decaying roots, burrow holes or movements caused by frost or wind-toppled trees, the results should be regarded with caution ${ }^{31}$.

In fact, problems relating to chronology do not only affect Finnish CWC graves. Indeed, despite earlier attempts ${ }^{32}$ regarding a typo-chronology and a handful of radiocarbon dates from Finnish graves (Appendix 1) and from settlement contexts ${ }^{33}$, the chronological division of Finnish CWC is rather vague. Even though differences can be seen, for example, in the tempering of pottery vessels, with some vessels tempered with mineral temper and some with organic temper, these different tempering styles seem to co-exist ${ }^{34}$. Similarly, no clear typochronology is present in vessel or axe types either ${ }^{35}$.

\section{\#Head 2\#The Finnish Corded Ware graves}

\section{\#Head 3\#Grave custom}

According to the available documentation, most of the Finnish CWC graves are earth graves with the form of the grave structure being either oval ( 8 graves) or rectangular ( 7 graves). If one also counts the more ambiguous settlement site pits, the number of both categories rises

\footnotetext{
30 Varul et al. 2019

${ }^{31}$ Mökkönen 2013, 21.

${ }^{32}$ See, e.g., Meinander 1954; Edgren 1970; Purhonen 1986.

${ }^{33}$ Nordqvist 2016, Table 1.

${ }^{34}$ Ibid. 60.

${ }^{35}$ Edgren 1970, 58-59; Nordqvist 2016, 61.
} 
to 11 graves each. According to the oral description of the laypersons, some of the graves could also have been covered with a small mound.

Aside from the possible mounds, some of the graves seem to have possessed an underground stone setting covering and/or surrounding the grave structure (e.g. Aimalankangas, Viikka, Itko, Kylänpää, Jyrkänkallio and Kuoppakangas graves). A well-sited example of such tradition is Kylänpää, from which three pits framed by large stones and filled with smaller stones were unearthed (Appendix 1). Since a sharp-butted axe and a work axe were collected as stray finds from the location, these pits were interpreted as Corded Ware graves ${ }^{36}$. However, without exact information on the find contexts, the axes cannot be reliably connected with the structures and the interpretation should thus be regarded with caution. A slightly different tradition of natural stone use has been documented from the Dalamalm earth grave, in which two large natural stones, one with triangular shape with the tip pointing upwards, were discovered from the south-western end of the grave ${ }^{37}$ (Figure 3). Similarly, the presence of a large natural stone at the bottom of the structure was noted in the possible grave of the Seppälä site (Appendix 1).

Most of the Finnish Corded Ware graves are oriented either NW-SE (4 graves) or E-W (4 graves). Occasionally, the orientation of the graves has been given with further intermediate points that fall in between these main orientations. In two cases, the grave was oriented NESW. Since the burials lack human remains, the orientation of the grave is based on the grave structure, and only in the case of the Perttulanmäki grave with its preserved human molar enamel was it possible to conclude that the deceased was positioned with their head to the east.

The depth of the Finnish Corded Ware graves varies in between shallow pits of $30 \mathrm{~cm}$ to deeper graves with a depth of $120 \mathrm{~cm}$. In general, the pits were dug to the depth of 50-100 $\mathrm{cm}$. Similarly, the parameters of the grave structures varied from large features of $400 \times 400$ $\mathrm{cm}$ to considerably smaller pits with dimensions of only $90 \times 40 \mathrm{~cm}$. Since most of the graves had been partly destroyed by modern land use, in many cases the exact sizes of the graves could not be determined.

When the parameters of the graves are observed from the angle of the grave type, it seems that both earth graves and graves with a possibly more monumental structure include larger and smaller graves. For example, although the plausible stone setting of the Itko grave was described as a large monument with a diameter of 4 metres, the stone setting of the

\footnotetext{
${ }^{36}$ Rosén 1953.

${ }^{37}$ Edgren 1970, 81.
} 
Jyrkänkallio grave was considerably smaller with a width of only a metre (Appendix 1). Similarly, the documentation of the oval and rectangular earth graves suggests that both structures came in different sizes.

\section{\#Head 3\#Burial custom}

In general, the Finnish CWC graves are wider than the prior hunter-gatherer earth graves of the Baltic region, in which the shape and size of the grave are usually adapted by the physical parameters of the body or bodies ${ }^{38}$. This could indicate that the deceased were mainly placed in a crouched position ${ }^{39}$. However, since narrow burial features also occur (e.g. Kuoppakangas grave, Forsberg grave and Jönsas grave V) occasionally, the body could also have been placed in a supine position, either extended or with flexed legs. However, it must be noted that of the narrow burials, the Kuoppakangas grave is not only located outside the core area of Corded Ware habitation (Figure 2) but it also included with two battle axe imitations (Appendix 1). In this sense, rather than being a 'proper' CWC burial, the grave might represent local hunter-gatherers that adopted the CWC way of life. This is an issue to which we shall later return in depth.

Most of the Finnish Corded Ware graves have been furnished with a single pottery vessel accompanied by varying amounts of stone artefacts (Appendix 1). This phenomenon seems to indicate that the graves were mainly single inhumations, although some exceptions nevertheless exist. For example, as many as three intact Corded Ware vessels were discovered from the Forsberg grave (Figure 4). These vessels were, however, positioned tightly together to the northern end of the E-W oriented grave structure (Figure 3b). Since the grave had the width of only c. $100 \mathrm{~cm}$, it seems reasonable to assume that this grave was nevertheless an individual burial.

If observed solely from the perspective of the size of the burial feature, the Itko burial (400 $\mathrm{x}$ $400 \mathrm{~cm}$ ) could represent either a double or a multiple/mass burial (Appendix 1). However, a better example of a possible double burial is Jönsas grave I, furnished with two pottery vessels (Appendix 1). Contrary to the above mentioned Forsberg grave, here the vessels were placed on the opposite sides of the grave structure (Figure 1), suggesting that this particular grave could have been a double burial ${ }^{40}$. This interpretation is further supported, on the other

\footnotetext{
${ }^{38}$ Nilsson Stutz 2003, 333-335; Lõhmus 2007, 37-40; see, however, Ahola et al. 2016, 111-112.

${ }^{39}$ Edgren 1984, 76.

${ }^{40}$ Purhonen 1986, 115-116.
} 
hand, by the size $(200 \times 250 \mathrm{~cm})$, and on the other, by the form of the grave structure, which seems to be constituted by two oval burial features side by side (Figure 1).

In many cases, the floor and/or walls of the Finnish Corded Ware graves have been covered with a dark, sooty soil. In previous studies ${ }^{41}$, this phenomenon has been explained with the use of fire as a part of the mortuary practice, but this phenomenon could also represent remains of an organic inner structure. For example, a wavy outline of the dark feature together with hook-shaped formations on the corners has led to the conclusion that some of the graves were furnished with animal skins ${ }^{42}$. This hypothesis was recently verified by new microarchaeological studies ${ }^{43}$ in which mineralized goat hairs were discovered from the Perttulanmäki grave (Figure 5). It must be noted, though, that in one case (Appendix 1: Tuomala grave), the dark layer located at the bottom of the grave was also described as having a greasy aspect. Although not ruling out the presence of an animal skin or other organic materials, the dark colour of the feature could also originate from decomposed human remains ${ }^{44}$.

\section{\#Head 3\#Material culture}

According to the collected data, the most common artefact from the Finnish CWC graves is a pottery vessel (24 items). The vessels are mainly beakers, although a few small cups also exist in the material (Figures 5 and 7). Aside from the graves of Jönsas I and Forsberg mentioned already earlier, the other graves have been furnished with a single vessel (Figure 7). In ten cases the beaker was the only grave object included in the burial. Indeed, a more common way to furnish the grave (21 instances) was to place the pottery vessel together with one or more stone artefacts (Figure 7). Although no evidence exists, objects made of organics materials could also have been placed to the graves.

When information on the positioning of the pottery vessels is available, the beakers seem to have been placed next to the walls of the grave structure, either in one of the corners of the grave (Figure 1) or roughly at the middle of the axis of the grave (Figure 3b). In the case of the Jyrkänkallio stone setting (Figure 3c), the pottery vessel was discovered beneath the largest stone of the setting, located at the centre of the structure ${ }^{45}$.

\footnotetext{
${ }^{41}$ Kivikoski 1934; Edgren 1958; Siiriäinen 1972.

42 Äyräpää 1931, 10-11; Torvinen 1979, 42-43.

${ }^{43}$ Ahola et al. 2018.

${ }^{44}$ See Lehtosalo-Hilander 1973, 165.

${ }^{45}$ Edgren 1970, 85; note, however, that the grave structure portrayed in Figure $3 \mathrm{c}$ is based on an oral description instead of excavation data.
} 
In most cases, the vessels have been discovered in sherds or broken in situ. Furthermore, the beakers consist often of only part of a vessel (Figure 8) while whole, intact vessels are rare. Since most of the pottery vessels have been discovered in shards, the positioning of the vessel is generally unknown. However, most of the Jönsas vessels (Figure 6) were discovered in an upward position, while one of the smaller beakers from the Forsberg grave was intentionally placed upside down (Appendix 1). In the Forsberg grave, rim sherds of household pottery were also used as part of the mortuary practice by placing them on top of the grave structure $^{46}$. A similar practice could be present as well in the cases of the possible graves of Yli-Hoppela 1 and Piirtolankangas (Figure 9), which include a Corded Ware vessel together with a large sherd from another vessel (Appendix 1).

Aside from pottery, battle axes are a common grave gift (16 items) in the Finnish CWC graves (Figures 7 and 9). In addition, two battle axe imitations or local copies (Figure 10) were discovered from one grave (Appendix 1: Kuoppakangas grave). In five cases, the battle axe - or axes - were the only artefact finds from the possible grave, suggesting that some stray finds of axes could also derive from graves. In most cases, however, the axes were accompanied by pottery vessels as well as other stone artefacts. Contrary to the battle-axes, four-sided axes ('working axes') have not been as commonly placed in the graves (5 items), while the presence of adzes (Figure 11) is slightly more common (9 items). Aside from these artefact types, four grinding stones are also known (Figure 11).

In rare cases of excavated graves in which the exact location of the artefacts has been documented (Appendix 1: Dalamalm grave, Jönsas graves I \& II, Perttulanmäki grave), it seems that stone artefacts and pottery vessels were positioned either on opposite ends of the grave or the axe or adze was placed at the centre of the grave structure, possible next to the body of the deceased. Stone artefacts have also been discovered near the walls of the grave structure (Figure 1).

\section{\#Head 3\#Locations}

Most of the Finnish Corded Ware graves (a total of 10) have been discovered as solitary graves. However, since the graves have been unearthed mainly due to modern land use and consist of stray finds, the find combinations could also represent grave assemblages of several destroyed individual graves or multiple burials. This could be the case, for example, for sites with various battle axes or adzes (Appendix 1: Tammenmäki and Pelttari sites; Figure 7b).

\footnotetext{
${ }^{46}$ Edgren 1958, 29.
} 
However, since the find location has only rarely been excavated, information on the find context is often lacking. Therefore, in many cases we do not know whether the graves represent a solitary grave, a single grave in a contemporary settlement site or an individual grave from a cemetery.

If the ambiguous settlement site pits are included, as many as nine possible graves have been discovered from a Corded Ware settlement site. In many cases, however, the possible settlement site context has not been excavated further and the dating of the site should be approached with caution. These sites have been marked in Appendix 1 with a question mark. Although most of these graves consist of single graves, a stone setting together with a possible rectangular earth grave without any finds have been unearthed from the Jyrkänkallio site (Appendix 1).

Aside from solitary graves and settlement site graves, in nine cases the CWC graves have been discovered either from a prior Neolithic hunter-gatherer settlement site ( 3 graves) or cemetery (6 graves). For example, the Kukkarkoski I grave was located within a Middle Neolithic cemetery of the Comb Ware culture (ca. 3900-3500) ${ }^{47}$ (Figure 12a), while the five graves of the Jönsas site - the only group of CWC graves known from the Finnish territory were discovered from a possibly earlier hunter-gatherer cemetery of over twenty ochre earth graves $^{48}$ (Figure 12b).

\section{\#Head 2\#Discussion}

\#Head 3\#Characterizing the Finnish CWC Graves

In light of the material presented in this study, the Finnish CWC graves can be characterized as rectangular or oval-shaped features oriented NW-SE or E-W, which have been discovered at a depth of ca. 50-100 cm. Even though the features lack human skeletal remains, the presence of stained, sooty soil, sometimes with a greasy aspect, indicates that these features are, in fact, earth graves with fully decomposed human remains.

The Finnish CWC graves have been most commonly furnished with a Corded Ware vessel. In the rare cases where the position of the vessel could be determined, it was placed either by the walls of the grave structure or in one corner. Although the exact location and orientation of the body in the Finnish CWC burials are unknown, this practice seems to follow the narrative of CWC material culture of death. For instance, by investigating the material culture of northern CWC graves as a whole, Quentin Bourgeois and Erik Kroon (2017) have noted that

\footnotetext{
47 Torvinen 1979.

${ }^{48}$ Purhonen 1986; Ahola 2017b.
} 
pottery was often positioned at the back of the body or placed on the northern edge of the burial pit. Even though the Finnish CWC graves do not always follow the E-W/W-E orientation of central European CWC graves, the pots might nevertheless have been positioned similarly to the foot of the grave (pottery located in the corner of the grave) or behind the back of the deceased (pottery located at the mid part of the grave wall). In many cases, the pottery vessel was accompanied by a battle axe or an adze. In the rare cases in which the position of the axe/adze was possible to determine, the items were located by the walls of the grave, clearly opposing the pottery vessel, or at the middle part of the grave. Remarkably, this tradition again echoes the material culture of death recorded from the central European CWC graves, in which battle axes (or flint axes) were placed in front of the body or face while flint blades were positioned on the pelvis of the deceased ${ }^{49}$. Although flint blades are unknown in the Finnish material, the location of an axe or an adze by the mid-part of the grave could suggest a connection with the pelvic area of the deceased, while the items positioned by the walls of the grave could have been located in front of the body or face. Although speculative, this phenomenon could also be used to determine the orientation of the burials. For example, since the axes discovered from Jönsas grave I were located by the SW wall of the grave (Appendix 1; Figure 1), the individual connected with them may have been buried with the head to the west.

Aside from pottery vessels and axes/adzes, other grave goods are only rarely encountered. For example, amber artefacts - common in the prior hunter-gatherer graves of the Finnish territory ${ }^{50}$ - are completely missing from the CWC graves. The graves could have been furnished with artefacts made of organic materials, however. Although speculative, this could explain the presence of the grave-like structures unearthed without any finds from the Finnish CWC settlement sites.

Judging from the size of the structure and the composition of the grave goods, the Finnish CWC graves seem to be mainly individual burials of bodies placed in a crouched position. On some rare occasions, however, the shape, size and the amount of artefacts suggest a multiple burial or a burial in supine position. Since these graves are clearly a minority, it seems that the burial custom and material culture of the Finnish CWC graves are rather uniform.

At the same time, however, variation clearly occurs in the grave custom. Indeed, according to the material presented in this study, some of the Finnish CWC graves could have possessed a small mound. Although in many cases this interpretation is based on the oral description

\footnotetext{
${ }^{49}$ Bourgeois/Kroon 2017.

${ }^{50}$ Ahola 2017a.
} 
given by the laypersons laymen who discovered Corded Ware artefacts (while graveling sand, for example), some of the graves from the Jönsas site were also connected with small arch-like ditches, a phenomenon that could relate to a mound that has been completely eroded $^{51}$.

A further variation can be seen in the inner structures of the graves. In fact, while some of the graves have been furnished with an underground stone setting, the rectangular shape of the grave structure could indicate that some graves might have possessed a wooden chamber as well. The structure is most evident in the case of the Kukkarkoski I grave, formed by a dark, sooty layer also consisting of pieces of charred pine trunk (Appendix 1), which covered large parts of the floor and the walls of the structure (Figure 13). In addition, the beaker of the grave was discovered as completely flattened (Figure 13), suggesting that the vessel had been located in an empty space that had been rapidly filled with sediment. A similar phenomenon might also be present in the case of Jönsas grave IV, which was visible already before the excavations as a shallow depression ${ }^{52}$. Similarly to the Kukkarkoski I grave, the walls of Jönsas grave IV were also partly framed by small fragments of charcoal and a small cup (Figure 6) unearthed from the grave discovered in sherds (Appendix 1).

Curiously, aside from the rectangular chambers, the presence of a wooden chamber has additionally been suggested in the case of the oval grave structure of the Forsberg site ${ }^{53}$ (Figure $3 b$ ). This structure was surrounded by a charcoal frame, and the burial layer of the grave, furnished with three intact Corded Ware beakers and shards from several other vessels (Figure 4), consisted of sooty, stained soil. On top of the burial layer was a $5 \mathrm{~cm}$ thick layer of unstained, sterile soil and, above this feature, another layer of sooty soil. From this layer, a rim sherd of household pottery was discovered. According to Edgren ${ }^{54}$, the wooden chamber of the Forsberg grave was most probably constructed of wooden planks placed in an upward position and covered with a lid. It seems that the beakers were placed in the burial layer while the rim sherds of the household pottery were positioned on top of the burial.

As these examples show, the grave custom of the Finnish CWC graves is far from uniform. Rather, it seems that in most cases the grave custom is different and no single typical architectural feature can be determined. Moreover, in order to complicate the picture even further, the Finnish CWC graves show variation in their location. They have been discovered either as solitary graves or as single graves in CWC settlement sites, or in prior hunter-

\footnotetext{
${ }^{51}$ See, e.g., Haak et al. 2008.

${ }^{52}$ Purhonen 1986, 118.

${ }^{53}$ Edgren 1958.

${ }^{54}$ Ibid., 31.
} 
gatherer settlement or cemetery sites. At the same time, it seems that proper cemeteries are missing from the record.

\#Head 3\#Variation, chronology and the cultural continuity in the Finnish CWC The detected variation is not completely unexpected, since CWC graves in different regions of Europe have been furnished with varying inner structures made of wood and stones, ${ }^{55}$ for example, while the graves themselves were located both as small cemeteries, situated in rows across the landscape, and as solitary graves ${ }^{56}$. At the same time, however, considerable similarities are present in the material culture and burial customs of these populations ${ }^{57}$. Initially, this phenomenon seems to suggest that, among the CWC populations, the location and grave custom were more negotiable than the material culture and burial custom among. What is interesting, however, is that in the Finnish territory, the detected variation is present within a single region.

Since the Finnish material lacks reliable radiocarbon determinations, it is difficult to detect temporal change. Evident nonetheless, however, is the contribution of the local huntergatherer populations of the Finnish territory. In fact, even though the Finnish CWC burials seem to follow the core mortuary practices of the CWC, sporadic connections to local huntergatherer material culture of death seem also to exist $\mathrm{t}^{58}$. For example, as was noted before, in the Forsberg grave, a small pottery vessel was placed upside down and rim sherds of household pottery were used as burial gifts. Although pottery is not common in Finnish hunter-gatherer burials, the presence of rim sherds and a vessel positioned upside down have counterparts within the hunter-gatherer material culture of death ${ }^{59}$. Indeed, when pottery is present in the hunter-gatherer graves, it has clearly warranted special treatment (for example, being placed upside down ${ }^{60}$. At the same time, rim sherds from hunter-gatherer pottery vessels have been used in particular either as grave objects or to line the walls of the graves ${ }^{61}$. The influence of hunter-gatherer populations can also be seen in the material culture of the Dalamalm and Kuoppakangas graves. Specifically, the metatuffite adze unearthed from the Dalamalm grave (Appendix 1; Figure 3a) originates from the Onega region in north-west Russia and is usually connected with the hunter-gatherer populations of the area ${ }^{62}$.

\footnotetext{
${ }^{55}$ Fischer 1956; Malmer 1962; Hansen 1994; see also Vander Linden 2007.

${ }^{56}$ Malmer 1962; Ebbesen 2006; Bourgeois 2013; Furholt 2014; Piličiauskas et al. 2018.

${ }^{57}$ Vander Linden 2007; Furholt 2014; Bourgeois/Kroon 2017.

58 Ahola 2019, 56

59 Ahola 2017a.

${ }^{60}$ Ibid., 207, 212.

${ }^{61}$ Ibid., 207.

62 Tarasov/Gogolev 2017.
} 
Accordingly, the presence of the item in a CWC grave context suggests that a contact network existed between the hunter-gatherers and CWC populations ${ }^{63}$. It must be noted, though, that metatuffite items originating from the Onega region are commonly discovered from the Finnish territory ${ }^{64}$. Thus, the Dalamalm metatuffite adze might not represent a direct link to north-west Russia but rather the influence of local hunter-gatherers of the Finnish territory. Compared to the Dalamalm grave, the Kuoppakangas grave presents a slightly different story, being furnished with two battle axe imitations that are likely of local production ${ }^{65}$. Compared to central European battle axes, these items (Figure 10) seem to lack the know-how of battle axe production and, as was mentioned already earlier, can thus represent a grave of local people adopting CWC identity or religion ${ }^{66}$.

The presence of social networks between the local hunter-gatherer populations and the CWC newcomers could also explain the presence of CWC graves in prior hunter-gatherer cemeteries and settlements; perhaps these important sites were introduced when new contact networks were formed, or the people buried in these places were indigenous people that had adopted the Corded Ware identity ${ }^{67}$. Since CWC graves have been discovered also from the Mesolithic and Neolithic hunter-gatherer cemeteries of Zvejnieki (Latvia) and Dolnkalnis (Lithuania) ${ }^{68}$, the phenomenon seems to be present outside the Finnish borders as well. It is necessary to point out, however, that the act of reuse within the Finnish and Baltic CWC is clearly occasional and selective; not all old burial or settlement sites were reused, and CWC graves were also constructed in other locations. In this sense, it seems that the CWC mortuary practices did not vary only regionally or temporally, but rather a multiplicity of mortuary practices must have co-existed.

When observed from yet another angle, the multiplicity of mortuary practices could also explain the small number of graves discovered from the Finnish territory, suggesting that the dead were also buried in ways that might not be visible to the archaeological record ${ }^{69}$. Interestingly, such a tradition again mirrors the mortuary traditions of the hunter-gatherer populations of the Baltic area, who not only buried their dead in varying locations (i.e. in settlement sites, cemeteries or as solitary graves) but also handled the deceased in various

\footnotetext{
${ }^{63}$ Edgren 1970, 59.

${ }^{64}$ Heikkurinen 1980.

65 Äyräpää 1952.

${ }^{66}$ Carpelan 2004, 57; Nordqvist/Häkälä 2014, 16-18.

${ }^{67}$ Ahola 2017a, 108-110; see also Larsson 2009, 255-260.

${ }^{68}$ Zagorskis 2004 [1989]; Butrimas 2012.

${ }^{69}$ Ahola 2019, 61-62.
} 
ways $^{70}$. Although no CWC cremations or loose human bones are known, for example, from the Finnish territory ${ }^{71}$, a recent study from Estonia ${ }^{72}$ has nevertheless suggested the presence of a multi-episode burial from a CWC grave context.

\#Head 3\#Finnish Corded Ware graves in their wider setting in North-Eastern Europe Having untangled some of the questions relating to the uniformity and variation found in the Finnish CWC graves, the next step is to look at the graves in their wider setting. As was noted above, the material culture of the Finnish CWC graves in general seems to follow the tradition present in central and northern Europe. Instead of western influence, however, the appearance of Finnish CWC has commonly been accorded to movement of people from the south-eastern Baltic Sea area to the modern-day territory of Finland ${ }^{73}$. In this sense, the best parallels for the Finnish CWC graves should be found in the eastern Baltic region.

At first glance, many of the practices present in the Finnish CWC funerary repertoire do indeed have parallels in the eastern Baltic area. Similarly to the Finnish material, the Baltic CWC graves (Figure 14) also consist of single graves or small cemeteries in which ca. 10 individuals have been interred, while larger cemeteries are clearly missing from the record ${ }^{74}$. For the most part, the graves additionally share the tradition of an underground, pit-grave burial without burial mounds ${ }^{75}$. In both cases, the interments have occasionally been discovered in prior hunter-gatherer cemeteries. Broadly taken, these elements can be used to define a Finnish-Baltic CWC grave (Figure 15).

Yet, contrary to the Finnish CWC graves, the eastern Baltic CWC graves are largely missing inner structures, such as wooden chambers or stone settings. Moreover, even if the archaeological evidence is vague, some of the Finnish CWC burials may have also been covered with a small mound. When the Finnish CWC graves are compared to the eastern Baltic in terms of their material culture, further differences emerge. Although pottery vessels are a common burial gift in Finnish CWC graves, the presence of pottery is rarer in the Baltic CWC graves $^{76}$. These graves are instead accompanied by items such as battle-axes, flint axes, large bladed flint knives, bone pins and wild boar (sus scrofa) tusks. Although it is unknown whether the Finnish CWC graves contained items made of bone or antler, other artefact types

\footnotetext{
${ }^{70}$ Brinch Petersen/Meiklejohn 2003; Lõhmus 2007; Nilsson Stutz 2003; 2010; Brinch Petersen 2016; Tõrv 2016; Ahola et al. 2016.

${ }^{71}$ Ahola 2019, 62.

72 Varul et al. 2019.

${ }^{73}$ Nordqvist 2018, 111-112 with cited references.

${ }^{74}$ Piličiauskas et al. 2018, 540; Varul et al. 2019.

${ }^{75}$ The only clear mound evidence is found in Kaliningrad oblast, burial of Kaup; Randborg et al. 2016.

${ }^{76}$ Piličiauskas et al. 2018, 540.
} 
commonly present in the Baltic CWC graves (e.g. flint axes and large bladed flint knives) are lacking from the Finnish graves.

Since Finnish CWC graves lack chronological resolution and internal division, the apparent differences in the material culture could be temporal. Indeed, many eastern Baltic CWC burials date early in the sequence and contain high amounts of Yamnaya (steppe) ancestry ${ }^{77}$. In this regard, the eastern Baltic CWC could represent 'the first wave of CWC' that has not interacted with the descendants of 'Danubian' farmers, who by that time were either of TRB or Globular Amphora cultural background. Aside from aDNA and radiocarbon determinations, this idea is supported further by the fact that the eastern Baltic CWC burials mainly lack pottery. Indeed, since pottery is not commonly encountered in Yamnaya burials ${ }^{78}$ or north-eastern hunter-gatherer burials ${ }^{79}$, the use of pottery as a grave gift could relate to CWC interactions with central European farming populations that commonly used pottery vessels in their funerary practices ${ }^{80}$. This interpretation is supported by the fact that early CWC burials in central and northern Europe widely lack pottery, too ${ }^{81}$. It thus seems reasonable to assume that the presence of pottery - often seen as an integral part of CWC mortuary repertoire - is actually the inheritance of farming society input, notably by women $^{82}$, and later adopted in the CWC funerary practice, not from its onset. The fact that the first wave of CWC populations must have interacted in the eastern Baltic area with hunter-gatherers, instead of farmers, has also resulted in the formation of what we now understand as the characteristics of this regional CWC group. In general, CWC of the eastern Baltic region differs from central and north European CWC in terms of its material culture and settlement. For example, the material culture of Finnish and eastern Baltic (and also Eastern Central Sweden) CWC show uniform features - such as globular beakers and bowls along with shared stylistic features of battle axes - not present in other areas inhabited by $\mathrm{CW}$ users ${ }^{83}$. Furthermore, in the territories of Estonia and Finland, CWC dwelling sites are often found at the locations of prior hunter-gatherer settlements ${ }^{84}$. A similar phenomenon has also been noted in Sweden, where CWC settlements have been found from Early Neolithic Funnel Beaker sites ${ }^{85}$. Since in many cases these sites had been abandoned already

\footnotetext{
${ }^{77}$ Saag et al. 2017; Mittnik et al. 2018.

${ }^{78}$ Heyd 2011.

${ }^{79}$ Larsson 2009; Ahola 2007a.

${ }^{80}$ Madsen 2019; see also Bourgeois/Kroon 2017.

${ }^{81}$ Furholt 2014, 73; see also the so-called Kalbsrieth graves of Central Germany: Kluttig 1994.

${ }^{82}$ Kristiansen et al. 2017, 339-340.

${ }^{83}$ Larsson 2009, 139-152, 256-258; Furholt 2014, 76; Nordqvist 2016.

${ }^{84}$ Edgren 1984, 75; Kriiska 2003.

${ }^{85}$ Larsson 2009, 68.
} 
a thousand years before, the co-existing populations might not have relied on the same resources as the CWC people. In fact, due to isostatic land uplift, such sites in Finland are located far from the seashore, the area preferred by the local hunter-fisher-gatherers for their settlements ${ }^{86}$. On the other hand, this may have made the co-existence of the CWC newcomers and the local populations more peaceful than, for example, in densely populated central Europe, where traces of violent encounters have been recorded ${ }^{87}$.

Aside from the differing use of resources, it is possible that the early $\mathrm{CWC}$ populations also shared cosmological aspects with the local hunter-gatherers. Indeed, even though the CWC populations likely brought the Indo-European cosmology with them ${ }^{88}$, their funerary practices nevertheless resonate with those of the local hunter-gatherers. In fact, the Baltic huntergatherers also buried their dead underground as individual (or occasional multiple) burials, which were well furnished but usually without pottery ${ }^{89}$. In this sense, it seems possible that the CWC people and the local hunter-gatherers of the eastern Baltic area shared the core idea of a proper burial ritual. Remarkably, this may have had an impact on how the local people and the newcomers regarded one another. Perhaps people burying occasional individuals underground were more relatable than people burying their dead, for example, in collective megalith burials, as was common in western and parts of central and northern Europe at the time (for an analysis of the complexity of such, see, e.g., Iversen 2015).

At the same time that the Baltic CWC people interacted with local hunter-gatherers, however, they were also part of a much larger network of northern and central European CWC. Over the course of centuries, people within this network moved back and forth, resulting, for example, in the adoption of pottery as part of the funerary repertoire in the eastern Baltic region. In terms of grave customs, common ground can also be seen, for instance, between Finnish, Polish and Belarussian CWC graves as well as with the burials of the Fatyanovo culture, the Volga catchment variant of CWC, which all share the tradition of rectangularshaped wooden chambers ${ }^{90}$. On the other hand, the best parallels for the Finnish underground stone settings can be found in Southern Scandinavia and Norway ${ }^{91}$. This idea of a 'melting pot' of traditions is shown also in a recent study concerning the manufacture of CWC pots ${ }^{92}$, according to which the CWC populations of the central and eastern Baltic region were highly

\footnotetext{
${ }^{86}$ See, e.g., Edgren 1984, 28.

${ }^{87}$ Kristiansen et al. 2017; Schroeder et al. 2019.

${ }^{88}$ Kristiansen et al. 2017.

${ }^{89}$ Zagorskis 2004 [1987]; Larsson 2009; Butrimas 2012; Tõrv 2016; Nilsson Stutz 2010; Ahola in press.

${ }^{90}$ Brjusov 1956; Asheichyk/Vaitovich 2016; Pospieszny et al. 2015.

${ }^{91}$ Malmer 1962; Ebbesen 2006.

${ }^{92}$ Holmqvist et al. 2018.
} 
mobile and carried new ideas and old traditions with them. These new ideas and old traditions could easily have also included death rituals.

Consequently, the eastern Baltic CW group - including also the Finnish CWC - can be seen as representing a fusion of ideas deriving both from CWC networks and from the local hunter-gatherers. These ideas could have been introduced via movement and migration, intermarriage or by adopting suitable local traditions. As the Kuoppakangas grave may show, the synchretism could go the other direction, too, with the local hunter-gatherers adopting parts of the CWC tradition.

\section{\#Head 2\#Conclusions}

In this paper, we have shown that while Finnish CWC graves are usually poorly documented and preserved, and primarily lack human remains and other perishable materials, they can nevertheless be examined further. Indeed, by focusing on the features that had preserved - the material culture of death, grave custom, and location of the burials - we were able to bring to light several new aspects of the Finnish CWC mortuary realm. For example, we were able to show that the graves not only reflect a material culture of death similar to the central and northern European CWC graves but the grave objects were also positioned in the grave in a similar manner. In addition, the Finnish graves also show evidence of the use of furs as part of the burial custom.

When we investigated the Finnish CWC grave materials from the perspective of location, we noted that the location of the burials varied from solitary graves to settlement site graves. Occasionally, graves we also located among hunter-gatherer burials. Aside from burial location, variation was also present within the grave custom. The inner and outer structures of the Finnish CWC graves vary from oval-shaped pit graves to graves with inner structures made of wood and stone. Likewise, the graves might also have been covered with stone settings or small barrows. Temporal variation notwithstanding, this phenomenon could suggest that the CWC people came from different origins. Indeed, even though it is very likely that the origins of the Finnish CWC might lie in the Baltic States, during the course of centuries a constant flow of new people from different regions may have migrated back and forth to the northernmost area inhabited by the CWC people. This idea is further supported by recent studies indicating a high degree of individual mobility among the CWC population of both central Europe and the eastern Baltic region ${ }^{93}$.

\footnotetext{
${ }^{93}$ Sjögren et al. 2016; Holmqvist et al. 2018.
} 
However, the Finnish CWC funerary custom was not solely influenced by different CWC populations but also by the local hunter-gatherers. In fact, as the Finnish CWC originates from an area where the CWC population had already mixed with local hunter-gatherers ${ }^{94}$, it is no wonder that hunter-gatherer mortuary traditions are present in the Finnish CWC graves. It is nevertheless evident that, in general, the Finnish CWC follows funerary traditions present in $3^{\text {rd }}$-millennium BC Europe. This, on the other hand, suggests that the novel worldview or even religion that spread across much of Europe during the $3^{\text {rd }}$ millennium $\mathrm{BC}$ also reached its northernmost corners.

\section{\#Head 2\#Acknowledgements}

We would like to thank Dr. Santeri Vanhanen/Lund for identifying wood remains and Dr. Torsten Edgren/Helsinki for providing archival information. This publication is supported by the ERC Advanced project 788616: The Yamnaya Impact on Prehistoric Europe (YMPACT) and the Doctoral School of History and Cultural Heritage at the University of Helsinki, for which we are grateful.

\section{\#Head 2\#References}

\#Head 3\#Archival sources

Arponen/Wallenius 1987: A. Arponen/T. Wallenius Vantaa Myyrmäki Jönsas /Paalutori. Kivi- ja varhaismetallikautisen asuin- ja hautapaikan kaivaus 1986. [Research report] National Heritage Agency (Helsinki 1987).

Äyräpää 1927: A. Äyräpää (Europaeus), Asuinpaikka- ja hautalöytö kivikaudelta Kiikoisten pitäjän Jaaran kylän Uudenjaaran talon maalta. Tutkimukset suorittanut maisteri A. Europaeus syyskuussa 1927. [Research report] National Heritage Agency (Helsinki 1927).

-1932: -, Kuoppakangas. Vasarakirveshaudan tarkastus 1932. [Research report] National Heritage Agency (Helsinki 1932).

-/Hukkinen 1949: -/E. Hukkinen, Vasarakirveshauta Kylmäkosken pitäjän Hautaan kylässä Maunulankulmalla. Tutk. Aarne Äyräpää \& Eino Hukkinen v. 1949. [Research report] National Heritage Agency (Helsinki 1949).

Bergström 1983: M. Bergström, Närpiö Pirttikylä Lokåsen. Kivikautisen asuinpaikan koekaivaus. [Research report] National Heritage Agency (Helsinki 1983).

Edgren 1999: T. Edgren, Myrskylä Kiparkatti. Vasarakirveen löytöpaikan kaivaus 1969. [Research report] National Heritage Agency (Helsinki 1999).

\footnotetext{
${ }^{94}$ Nordqvist 2018, 116; see also Saag et al. 2017 and Mittnik et al. 2018 for ancient DNA admixture evidence.
} 
Hackman 1913: A. Hackman, Ilmajoki Jouppila Piirtola. Kivikautisen asuinpaikan kaivaus 1913. [Research report] National Heritage Agency (Helsinki 1913).

Hukkinen 1951: E. Hukkinen, Sääksmäki Itko Vasarakirveshaudan kaivaus 1950. [Research report] National Heritage Agency (Helsinki 1951).

Kivikoski 1936: E. Kivikoski, Löydökset E. Kivikosken kaivauksesta Liedon pit. Viikan til. maalla, ns. Jyrkänkallion hiekkakuopalla. [Find catalogue] National Heritage Agency (Helsinki 1936).

Leppäaho 1936: J. Leppäaho, Viikan yksinäistila. Kivikautisen hautalöytöpaikan tarkastus 1936. [Research report] National Heritage Agency (Helsinki 1936).

Meinander 1938: C.F. Meinander, Löydöt kivikautisesta haudasta Mynämäen valasten kylän Tuomalan talon maalla. [Find catalogue] National Heritage Agency (Helsinki 1938).

Ojonen/Linturi 1979: S. Ojonen/E. Linturi, E., Vantaa, Myyrmäki, Jönsas. Kivi- ja varhaismetallikautisen asuinpaikka-alueen tutkimus- ja koekaivaukset kesällä 1976. [Research report] National Heritage Agency (Helsinki 1979).

Pälsi 1937: S. Pälsi, Tottijärven Pelttarinmäen kivikautinen kalmisto. [Research report] National Heritage Agency (Helsinki 1937).

Rosén 1951: G. Rosén, Arkeologisia tutkimuksia Vehkalahdella. [Research report] National Heritage Agency (Helsinki 1951).

Salmo 1958: H. Salmo, Tarkastusmatka Lahden kaupungin Okeroisten Koivulan tilan maalle, Kasakkamäen rinteeseen 21.X. 1958. [Research report] National Heritage Agency (Helsinki 1958).

Seger 1986: T. Seger, Vantaa Myyrmäki Jönsas. Kertomus kivi- ja varhaismetallikautisen asuin- ja kalmistoalueen kaivauksesta (S. Ojonen 1977). [Research report] National Heritage Agency (Helsinki 1986).

Voionmaa 1935: J. Voionmaa, Aimala, Littunen. Venekirveshautapaikan tarkistus 1935. [Research report] National Heritage Agency (Helsinki 1935).

\section{\#Head 3\#Unpublished sources}

Hecht 2007: D. Hecht, Das Siedlungswesen der Schnurkeramik im südlichen Mitteleuropa. Eine Studie zu einer vernachlässigten Fundgattung im Übergang vom Neolithikum zur Bronzezeit. PhD.University of Heidelberg. Available at: http://www.ubheidelberg.de/archiv/7313.heidelberg. [Accessed 19 May 2019].

\section{\#Head 3\#Literature}

Ahola 2015: M. Ahola, Tracing Neolithic Funerary Practices from Finnish Ochre Graves - A case Study from Kukkarkoski Comb Ware burial ground. Thanatos 2, 2015, 23-41.

- 2017a: -, The material culture of Finnish Stone Age hunter-gatherer burials. Fornvännen 4, 2017, 201-215. 
- 2017b:-, Memory, Landscape \& Mortuary Practice: understanding recurrent ritual activity at the Jönsas Stone Age cemetery in southern Finland. Acta Archaeologica 88, 2016, 95-120.

-et al. 2016:-/K. Salo/K. Mannermaa, Almost Gone: Human Skeletal Material from Finnish Stone Age Earth Graves. Fennoscandia Archaeologica XXXIII, 2016, 95-122.

- et al. 2018: -/T. Kirkinen/K. Vajanto/J. Ruokolainen, On the scent of an animal skin: new evidence on Corded Ware mortuary practices in Northern Europe.

Antiquity 361, 2018, 118-131

- 2019. Death in the Stone Age: Making Sense of Mesolithic-Neolithic Mortuary Remains from Finland (ca. 6800 to 2300 cal BC) (Helsinki 2019).

Allentoft et al. 2015: M.E. Allentoft/M. Sikora/K-G Sjögren/S. Rasmussen/J. Stenderup et al., Population genomics of Bronze Age Eurasia. Nature 522, 2017, 167-172.

Asheichyk/Vaitovich 2016: V. Asheichyk/A. Vaitovich, A Late Neolithic burial from the Drazny 12 site in the Upper Neman Region (Western Belarus). Lietuvos Archeologija 42, 2016, 105-125.

Äyräpää 1915: Äyräpää (Europaeus), A., Förvarv till Statens Historiska Museum år 1913. Den förhistoriska avdelningen. Finskt Museum 1915, 1-19.

- 1931: -, Kauhavan Perttulanmäen kivikautinen hauta. Suomen museo 38, 1-15.

- 1939:-, Suomen kivikauden kulttuurimuodot. Suomalaisen tiedeakatemian esitelmät ja pöytäkirjat 1937, 101-126.

- 1973: -, Båtyxkulturen i Finland. Opera selecta. Helsingin yliopiston arkeologian laitos, moniste 9, 1973, 195-211.

Bläuer/Kantanen 2013: A. Bläuer/J.Kantanen, Transition from hunting to animal husbandry in Southern, Western and Eastern Finland: new dated osteological evidence. Journal of Archaeological Science 40, 2013, 1646-1666.

Bourgeois 2013: Q. Bourgeois, Monuments on the Horizon. The Formation of the Barrow Landscape throughout the $3^{\text {rd }}$ and $2^{\text {nd }}$ Millennium BC (Leiden 2013).

- /Kroon 2017: -/E. Kroon, The impact of male burials on the construction of Corded Ware identity: Reconstructing networks of information in the $3^{\text {rd }}$ millennium BC. PLoS ONE, 12 , 2017.

Butrimas 2012: A. Butrimas, Donkalnio ir Spigino Mezolito-Neolito kapinynai. Seniausi laidojimo paminklai lietuvoje (Vilnius 2012).

Brjusov 1956: A. J. Brjusov, Eines der Merkmale des gemeinsamen der vorgeschichtlichen Stämme im europäischen und westsibirischen Teil der Sowjetunion. Suomen museo 62, 1956, 79-89.

Carpelan 1999: C. Carpelan, Käännekohtia Suomen esihistoriassa aikavälillä 5100-1000 eKr. In: P. Fågelberg (Ed.), Pohjan poluilla: Suomalaisten juuret nykytutkimuksen mukaan. Bidrag till kännedom av Finlands natur och folk 153 (Helsinki 1999) 249-280. 
- 2004: -, Corded Ware Culture in northern Finland. In: M. Lavento (Ed.) Early in the North: The Land. Iskos 13 (Helsinki 2004), 47-62.

Cramp et al. 2014: L. J. E. Cramp/R. P. Evershed/M. Lavento/P. Halinen/K. Mannermaa/M. Oinonen/J. Kettunen/M. Perola/P. Onkamo/V. Heyd, Neolithic dairy farming at the extreme of agriculture in northern Europe. Proceedings of the Royal Society B, Biological Sciences $17912014,1-9$.

Dörfler/Müller 2008: W. Dörfler/J. Müller, J. (Eds.), Umwelt - Wirtschaft - Siedlungen im dritten vorchristlichen Jahrtausend Mitteleuropas und Südskandinaviens (Kiel 2008).

Ebbesen 2006: K. Ebbesen, The Battle Axe Period. Stridsøksetid (Copenhagen 2006).

Edgren 1958: T. Edgren, Ekenäs-graven. Ett bidrag till kännedomen om båtyxkulturen i östra Nyland. Finskt Museum, LXV, 1958, 27-49.

- 1970: -, Studier över den snökeramiska kulturens keramik i Finland.

Suomen Muinaismuistoyhdistyksen Aikakauskirja 72 (Helsinki 1970).

- 1984: -, Kivikausi. In: Y. Blomstedt (Ed.) Suomen historia I (Espoo 1984), 19-97.

- 2007: -, On the non-megalithic mortuary practices in Finland. In: L.

Larsson/ F. Lüth /T. Terberger (Eds.), Innovation and continuity - Non-Megalithic Mortuary

Practices in the Baltic. New Methods and Research into the Development of Stone Age

Society. International Workshop at Schwerin on 24-26 March 2006. Bericht der RömischGermanischen Kommission 88 (Mainz am Rhein 2007) 501-520.

Fischer 1956: U. Fischer, Die Gräber der Steinzeit im Saalegebiet: Studien über neolithische und frühbronzezeitliche Grab- und Bestattungsformen in Sachsen-Thüringen (Berlin 1956).

Furholt 2014: M. Furholt, Upending a 'Totality': Re-evaluating Corded Ware Variability in Late Neolithic Europe. Proceedings of the Prehistoric Society 80, 2014, 67-86.

Haak et al. 2015: W. Haak/I. Lazaridis/N. Patterson/N. Rohland/S. Mallick/B. Llamas et al., Massive migration from the steppe was a source for Indo-European languages in Europe.

Nature 522, 2015, 207-211.

Halinen 2015: P. Halinen, Kivikausi. In: G. Haggrén/M. Lavento/A. Wessman/S. Raninen (Eds.), Muinaisuutemme jäljet: Suomen esi- ja varhaishistoria kivikaudelta keskiajalle (Helsinki 2015), 19-124.

Hansen 1994: M. Hansen, Wooden burial cists from the Single Grave Culture and the Late Neolithic. KUML - Årbog for Jysk Arkæologisk Selskab, 1993-94, 87-146.

Heikkurinen 1980: T. Heikkurinen, Itäkarjalaiset tasa- ja kourutaltat. Helsingin yliopiston arkeologian laitos, moniste 21 (Helsinki 1980).

Heyd 2011: V. Heyd, Yamnaya groups and tumuli west of the Black Sea. In: E. Borgna/S. Müller-Celka (Eds.), Burial mounds in the Copper and Bronze Ages (Central and Eastern Europe - Balkans - Adriatic - Aegean, 4th-2nd millennium B.C.). TMO 58 (Lyon 2011), $535-555$.

Holmqvist et al. 2018: E. Holmqvist/Å.M. Larsson/A. Kriiska/V. Palonen/P. Pesonen/K. Mizohata/P. Kouki/J. Räisänen, Tracing grog and pots to reveal Neolithic Corded Ware 
Culture contacts in the Baltic Sea Region (SEM-EDS, PIXE). Journal of Archaeological Science 91, 2018, 77-91.

Iversen 2015: R. Iversen. The Transformation of Neolithic Societies: An Eastern Danish Perspective on the 3rd Millennium BC (Højbjerg 2015).

Johanson 2006: K. Johanson, The contribution of stray finds for studying everyday practices: the example of stone axes. Estonian Journal of Archaeology 10, 2006, 99-131.

Jones et al. 2017: E. R. Jones/G. Zarina/V. Moiseyev/E. Lightfoot/P. Nigts/A. Manica/R. Pinhasi/D. G. Bradley, The Neolithic Transition in the Baltic Was Not Driven by Admixture with Early European Farmers. Current Biology 27, 2017, 1-7.

Kivikoski 1934: E. Kivikoski, Paimion Rukkijoen vasarakirveshauta. Suomen museo 41, 1934, 34-40.

Kluttig 1994: R. Kluttig, Bemergungen zur Gruppe Kalbsrieth (Kar). In: H.-J. Beier/R. Einicke (Eds.), Das Neolithikum im Mittelelbe-Saale-Gebiet und in der Altmark. Eine Ubersicht und ein Abriß zum Stand der Forschung. Beiträge zur Ur- und Frühgeschichte Mitteleuropas 4 (Wilkau-Hassau 1994), 311-320.

Kriiska 2003: A. Kriiska, From hunter-gatherer to farmer - changes in the Neolithic economy and settlement on Estonian territory. Archaeology Lituana 4, 2003, 11-26

Kristiansen et al. 2017: K. Kristiansen /M. E. Allentoft/K. M. Frei/R. Iversen, Re-theorising mobility and the formation of culture and language among the Corded Ware Culture in Europe. Antiquity 356, 2017, 334-347.

Larsson 2009: Å.M. Larsson, Breaking and Making bodies and pots. Material and ritual Practices in Sweden in the Third Millenium BC. Aun 40 (Uppsala 2009).

Lehtosalo-Hilander 1973: P-L. Lehtosalo-Hilander,

Ruumishautakaivaukset. In: P. Purhonen/L. Söyrinki (Eds.), Arkeologin kenttätyöt (Lahti 1973), 141-70.

Leskinen 2001: S. Leskinen, Kaivaustuloksia Pornaisten Myllyniityn asuinpaikalta. In: H. Ranta (Ed.), Kentältä poimittua: kirjoitelmia arkeologian alalta 5 (Helsinki 2001), 20-33

Lõhmus 2007: M. Lõhmus, Mortuary practices during the Comb Ware cultures in Estonia and the problems of their interpretation. In: A. Merkevicius (Ed.) Colours of archaeology. Material Culture and the Society. Papers from the Second Theoretical Seminar of the Baltic Archaeologists (BASE) held at the University of Vilnius, Lithuania, October 21-22 2005. Interarchaeologia 2 (Tartu 2007), 33-48.

Lõugas et al. 2007: L. Lõugas/A. Kriiska/R. Maldre, New dates for the Late Neolithic Corded Ware Culture burials and early husbandry in the East Baltic region. Archaeofauna 16, 2007, 21-31.

Luho 1965: V. Luho, Esihistoria. Helsingin pitäjän historia I (Helsinki 1965), 7-92.

Madsen 2019: T. Madsen, Pots for the Ancestors. The structure and meaning of pottery depositions at passage graves. In: J. Müller/M. Hinz/M. Wunderlich (Eds.), Megaliths Societies - Landscapes Early Monumentality and Social Differentiation in Neolithic Europe. Proceedings of the international conference 'Megaliths - Societies - Landscapes. Early 
Monumentality and Social Differentiation in Neolithic Europe' $\left(16^{\text {th }}-20^{\text {th }}\right.$ June 2015$)$ in Kiel. Frühe Monumentalität und soziale Differenzierung 18 (Bonn 2019) 893-920.

Malmer 1962: M.P. Malmer, Jungneolithische Studien. Acta Archaeologica Lundenesia 2 (Lund 1962).

Matiskainen 1994: H. Matiskainen, Essay ber die Ekonomie, die Migration und die Adaption des Einheitshorizontes der Schnurkeramik speziell unter dem Gesichtspunkt des OstBalticums und Finnlands. Suomen Museo 100, 1994, 9-26.

Meinander 1954: C.F. Meinander, Die Kiukaiskultur. Suomen Muinaismuistoyhdistyksen Aikakauskirja 53 (Helsinki 1954).

Mittnik et al. 2018: A. Mittnik/C-C Wang/S. Pfrengle/M. Daubaras/G. Zarina/F. Hallgren/R. Allmäe et al., The genetic prehistory of the Baltic Sea region. Nature Communications 9, 442, 2018.

Mökkönen 2013: T. Mökkönen, Stone setting filled with red ochre from the Keelaharju site, northernmost Baltic Sea region: a Stone Age grave in the context of north European burial traditions. Fennoscandia Archaeologica XXX, 2013, 13-36.

Müller et al. 2009: J. Müller/T. Sergély/C. Becker/A-M. Christensen/M. Fuchs/H. Kroll/D. Mischka/U. Schüssler, A Revision of Corded Ware Settlement Pattern -New Results from the Central European Low Mountain Range. Proceedings of the Prehistoric Society 75, 2009, $125-142$.

Nilsson Stutz 2003: L. Nilsson Stutz, Embodied Rituals \& Ritualized Bodies. Tracing Ritual Practices in Late Mesolithic Burials. Acta Archaeologica Lundensia 46 (Stockholm 2003).

- 2010:-, A Baltic Way of Death? A Tentative Exploration of Identity in Mesolithic Cemetery Practices. In: Å.M. Larsson/L. Papmehl-Dufay (Eds.) Uniting Sea II. Stone Age Societies in the Baltic Region. Occasional Papers in Archaeology 51 (Uppsala 2010), 127144.

Nordqvist 2016: K. Nordqvist, From Separation to Interaction: Corded Ware in the Eastern Gulf of Finland. Acta Archaeologica 87, 2016, 49-84.

-2018: -, The Stone Age of north-eastern Europe 5500-1800 calBC: bridging the gap between the East and the West (Oulu 2018).

- / Häkälä 2014: -/P. Häkälä, Distribution of Corded Ware in the areas north of the Gulf of Finland - An update. Estonian Journal of Archaeology, 18, 2014, 3-29.

Parker Pearson 1999: M. Parker Pearson, The Archaeology of Death and Burial (Thrupp 1999).

Pesonen et al. 2019: P. Pesonen/Å.M. Larsson/E. Holmqvist, The Chronology of Corded Ware Culture in Finland - Reviewing New Data. Fennoscandia archaeologica XXXVI, 2019, $130-141$.

Piličiauskas et al. 2018: G. Piličiauskas/V. Asheichyk/G. Osipowicz/R. Skipitytė/L. Varul/J. Kozakaite et al., The Corded Ware culture in the Eastern Baltic: New evidence on chronology, diet, beaker, bone and flint tool function. Journal of Archaeological Science: Reports 21, 2018, 538-552. 
Pospieszny et al. 2015: L. Pospieszny/I. Sobkowiak-Tabaka/T.D. Price/K.M. Frei/I.

Hildebrandt-Radke/H. Kowalewska-Marszałek/M. et al., Remains of a late Neolithic barrow at Kruszyn. A glimpse of ritual and everyday life in early Corded Ware societies of the Polish Lowland. Praehistorische Zeitschrift 90, 2015,185-213.

Purhonen 1986: P. Purhonen, Vantaan Jönsaksen nuorakeraamiset haudat. Iskos 6, 1986, $113-$ 125.

Ranborg et al. 2016: K. Randborg/I. Merkytè/A./V. I. Kulakov, Kaup 2014: Archaeological excavations \& research history. Acta Archaeologica 87/1, 2016, 85-130.

Saag et al. 2017: L. Saag/L. Varul/C.L. Scheib/J. Stenderup/M.E. Allentoft, M.E./L.

Pagani/M. Reidla et al., Extensive farming in Estonia started through a sex-biased migration from the steppe. Current Biology 27, 2017, 2185-2193.

Schroeder et al. 2019: H. Schroeder/A. Margaryan/M. Szmyt/B. Theulot/P. Włodarczak/S. Rasmussen et al.,Unraveling ancestry, kinship, and violence in a Late Neolithic mass grave. Proceedings of the National Academy of Sciences, May 2019, 201820210.

Siiriäinen 1974: A. Siiriäinen, Nuorakeraamisen kulttuurin hauta Teuvalla. Suomen museo 81, 1974, 5-14.

Sjögren et al. 2016: K-G Sjögren/T. Douglas Price/K. Kristiansen, Diet and Mobility in the Corded Ware of Central Europe. PLoS One 33, 2016.

Swain 2012: H. Swain, Archive Archaeology. In: R. Skeates/C. McDavid/J. Carman (Eds.) The Oxford Handbook of Public Archaeology (Oxford 2012), 351-372.

Tarasov/Gogolev 2017: A. Tarasov/M. Gogolev, ICP-MS Analysis of Metatuff from Middle Neolithic/Eneolithic 'Green Slate' Workshops in Lake Onega Area. Fennoscandia archaeologica XXXIV, 2017, 32-45.

Tõrv 2016: M. Tõrv, Persistent Practices: Multi-disciplinary Study of Hunter-gatherer Mortuary Remains from c. 6500-2600 cal. BC,

Estonia. Dissertationes Archaeologiae Universitatis Tartuensis 5 (Tartu 2016).

Torvinen 1979: M. Torvinen, Liedon Kukkarkosken kivikautinen kalmisto. Suomen museo 82, 1979, 37-80.

Vander Linden 2007: M. Vander Linden, For equalities are plural: Reassessing the social in Europe during third Millenium BC. World Archaeology 39/2, 2007, 177-193.

Varul et al. 2019: L. Varul/R.M. Galeev/A.A. Malytina/M. Tõrv/S.V. Vasilyev/L. Lõugas/A. Kriiska, Complex mortuary treatment of a Corded Ware Culture individual from the Eastern Baltic: A case study of a secondary deposit in Sope, Estonia. Journal of Archaeological Science: Reports 24, 2019, 463-472.

Zagorskis 2004 [1987]: F. Zagorskis, Zvejnieki (Northern Latvia) Stone Age Cemetery. Translated by V. Bērzinśs. BAR International Series 1292 (Oxford 2004). 